\title{
Evaluation of Fungicides and Botanicals against Major Seed-Borne Pathogen of Chickpea Seed Isolated from Tikamgarh District of Madhya Pradesh, India
}

\author{
Vandana Chadar*, Shraddha Karcho, Mahesh B. Ghuge and R. R. Bhanwar \\ Department of Plant Pathology, College of Agriculture, Tikamgarh, J. N. K. V. V., \\ Jabalpur (M.P.), India \\ *Corresponding author
}

\section{A B S T R A C T}

\section{Keywords}

Fungicides, Botanicals, Seed borne pathogens, Chickpea and poisoned food technique

Article Info

Accepted: 07 November 2019 Available Online: 10 December 2019
The present study revealed that the growth of $R$. bataticola was effectively inhibited $(100 \%)$ by all the fungicides viz., Carbendazim $(0.2 \%)$, Carboxin $(0.2 \%)$, Mancozeb $(0.2 \%)$, Carbendazim $(0.1 \%)+$ Carboxin $(0.1 \%)$ except inhibition $(23.28 \%)$ by Neem extract $5 \%$. Similar trend was observed in pathogens viz., F. oxysporum f. sp. ciceri, Penicillium spp. and A. niger. The completely growth $(100 \%)$ was inhibited by fungicides Carbendazim $(0.2 \%)$, Carboxin $(0.2 \%)$, Carbendazim $(0.1 \%)+$ Carboxin $(0.1 \%)$ followed by Mancozeb $(77.49,75.60$ and $74.52 \%)$. Whereas Neem extract was resulted in poor inhibition of the pathogens $(74.56,48.41$ and $43.97 \%)$. The seed-borne pathogens Rhizopus spp. was effectively completely (100\%) inhibited by the Carbendazim $(0.1 \%)+$ Carboxin $(0.1 \%)$ followed by Carboxin (42.34\%), Mancozeb (30.98\%), Carbendazim (23.49\%) and the lowest inhibition of the pathogens radial growth was showed by the Neem extract $(23.43 \%)$.

\section{Introduction}

Chickpea (Cicer arietinum) is one of the most important pulse crops district Tikamgarh of Madhya Pradesh. In Madhya Pradesh, the chickpea production was 22.97 lac tonnes from an area of 26.21 lac ha with an average productivity of $877 \mathrm{~kg} \mathrm{ha}^{-1}$ during 2015-16 ${ }^{1}$. In Tikamgarh district, the annual production was 240.26 tonnes from 20.26 ha with an average productivity $1200 \mathrm{~kg} / \mathrm{ha}^{2 \& 3}$.

Chickpea cultivation is often subjected to significant yield losses due to insects and diseases ranging from $5-10 \%$ in temperate and $50-100 \%$ in tropical regions ${ }^{4}$.

Currently chickpea is affected by 172 pathogens of which 67 fungi, 3 bacteria, 22 
viruses and mycoplasma, and 80 nematodes reported from 55 countries. Maximum number of pathogens infecting chickpea (89) had been reported from India while in other countries, it varied from 1 to $40^{5}$. Important fungal diseases of chickpea and their causal organisms are Dry root rot (Rhizoctonia bataticola), Fusarium wilt (Fusarium oxysporum $f$. sp. ciceri), Seedling/ seed rot (Aspergillus niger), Ear rot of maize (Penicillium sp.), soft rot of vegetables (Rhizopus sp.)

Despite of different diseases, Fusarium wilt is most important disease of chickpea causes severe damage. Although the disease is wide spread in the chickpea growing areas of the world and most prevalent in the Mediterranean Basin and the Indian subcontinent ${ }^{6}$. The dry root rot $(R$. bataticola) is an important plant pathogen with worldwide distribution and wide host range and with variable characteristics. The species $R$. bataticola is a pathogen of over 290 plant species ${ }^{7}$. In view of its importance and significance of seedborne diseases of chickpea, evaluation of fungicides and bio-pesticides against major seed-borne pathogens of chickpea seed invitro was carried out.

\section{Materials and Methods}

\section{Evaluation of seed dressing fungicides}

This study was carried out to know the efficacy of different seed dressing fungicides in eliminating the seed-borne fungal infections in the infected seed sample. The fungicides were tested initially under in vitro condition by using poison food technique ${ }^{8}$.

The trade name, common name and chemical names of fungicides used in the experiment are given below (Table 1).

All the fungicides were tested at recommended by adopting poisoned food technique. The test pathogen was grown on PDA medium in Petri plates for seven days prior to setting up of experiment.

The required fungicidal suspension was added to the melted PDA medium to obtain the desired concentration on the basis of active ingredients present in the chemical. $20 \mathrm{ml}$ of poisoned medium was poured in each Petri plate. Suitable checks were maintained without addition of fungicides.

A mycelial disc of five $\mathrm{mm}$ diameter was taken from the periphery of 7 days old colony and placed in the centre and incubated at $28 \pm$ $2^{\circ} \mathrm{C}$ for full growth of the fungus. Three replications were maintained for each treatment. The radial growth of the colony was measured in two directions and average was recorded. Per cent inhibition was recorded by using the formula as under':

$\mathrm{PI}=[(\mathrm{C}-\mathrm{T}) / \mathrm{C}] \times 100$

Where, $\mathrm{PI}=$ Per cent inhibition, $\mathrm{C}=$ Growth in control, $\mathrm{T}=$ Growth in treatment

\section{Evaluation of plant extract}

These plant extracts were tested initially under in-vitro condition by using poison food technique. The fresh leaves were grounded in a blender with distilled water.

The extract was filtered through double layered muslin cloth. The extracts were tried at concentration of 5 per cent for seed treatment, prepared by diluting the extract in distilled water.

\section{Preparation of cold aqueous extract}

Fresh plant material were collected and washed first in tap water and then in distilled water. 100 grams of fresh sample was chopped and then crushed in a surface sterilized pestle 
and mortar by adding $100 \mathrm{ml}$ sterile water (1:1 w/v). The extract was filtered through two layers of muslin cloth and the filtered was used as stock solution.

To study the antifungal mechanism of plant extract, the poisoned food technique ${ }^{8} .5$ and $10 \mathrm{ml}$ of stock solution was mixed with $95 \mathrm{ml}$ and $90 \mathrm{ml}$ of sterilized molten PDA media respectively so as to get 5 and 10 per cent concentration.

The medium was thoroughly shaken for uniform mixing of extract. $20 \mathrm{ml}$ of medium was poured into sterile Petri dishes. Day Mycelium of $5 \mathrm{~mm}$ size disc taken from periphery of 7 day old culture were cut out by sterile cork borer and one such disc was placed on the centre of each agar plate. Control was also maintained by growing the pathogen on PDA plates.

Each treatment was replicated thrice and plates were incubated at $20 \pm 2^{\circ} \mathrm{C}$ till control plates reached the radial growth of $90 \mathrm{~mm}$. The per cent inhibition over control was calculated by the formula given below ${ }^{9}$.

\section{Results and Discussion}

Among the different fungicides and biopesticide Table 1-3, figure 1 and chart-1, the growth of $R$. bataticola was effectively inhibited $(100 \%)$ by all the fungicides viz., Carbendazim (0.2\%), Carboxin (0.2\%), Mancozeb $(0.2 \%)$, Carbendazim $(0.1 \%)+$ Carboxin $(0.1 \%)$ except inhibition $(23.28 \%)$ by Neem extract 5\%. Similar trend was observed in pathogens viz., $F$. oxysporum f. sp. ciceri, Penicillium spp. and A. niger.

The completely growth (100\%) was inhibited by fungicides Carbendazim (0.2\%), Carboxin $(0.2 \%)$, Carbendazim $(0.1 \%)+$ Carboxin $(0.1 \%)$ followed by Mancozeb (77.49, 75.60 and $74.52 \%)$. Whereas Neem extract was resulted in poor inhibition of the pathogens (74.56, 48.41 and 43.97\%).

Table.1 List of fungicides used in the experiment

\begin{tabular}{|c|c|c|c|}
\hline $\begin{array}{c}\text { S. } \\
\text { N. }\end{array}$ & $\begin{array}{c}\text { Common } \\
\text { Name }\end{array}$ & Trade name & Chemical name \\
\hline $\mathbf{1 .}$ & Carbendazim $(0.2 \%)$ & Bavistin 50\% WP & 2-(methoxy carbomyl )-benzimidazol \\
\hline $\mathbf{2 .}$ & Carboxin $(0.2 \%)$ & $\begin{array}{c}\text { Vitavax powder } \\
75 \% \mathrm{WP}\end{array}$ & $\begin{array}{c}\text { 5,6-dihydro-2-methyl-1,4-oxathiin-3- } \\
\text { carboxamide }\end{array}$ \\
\hline $\mathbf{3 .}$ & Mancozeb $(0.2 \%)$ & Maneb 75\%WP & Ethylene-bisdithiocarbamates \\
\hline $\mathbf{4 .}$ & $\begin{array}{c}\text { Carbandazim }(0.1 \%) \\
\text { +Carboxin }(0.1 \%)\end{array}$ & $\begin{array}{c}\text { Bavistin + vitavax } \\
\text { powder }\end{array}$ & $\begin{array}{c}\text { 2-(methoxy carbomyl)-benzimidazol + 5,6- } \\
\text { dihydro-2-methyl-1,4-oxathiin-3-carboxamide }\end{array}$ \\
\hline
\end{tabular}

Table.2 Name of the bio-pesticide used in experiment

\begin{tabular}{|c|c|c|c|c|}
\hline S.N. & Botanical name & Common name & Family & Used plant part \\
\hline 1. & A. indica & Neem & Meliaceae & Leaf \\
\hline
\end{tabular}


Table.3 Percent inhibition of radial growth of seed-borne pathogens of chickpea in in-vitro

\begin{tabular}{|c|c|c|c|c|c|c|c|c|c|c|}
\hline \multirow{3}{*}{$\begin{array}{c}\text { Fungicides and Bio- } \\
\text { pesticide }\end{array}$} & \multicolumn{10}{|c|}{ Mean growth (mm) of seed-borne pathogens and inhibition over control (\%). } \\
\hline & \multicolumn{2}{|c|}{ R. bataticola } & \multicolumn{2}{|c|}{ A. niger } & \multicolumn{2}{|c|}{$\begin{array}{c}\text { F. oxysporum f. sp. } \\
\text { ciceri }\end{array}$} & \multicolumn{2}{|c|}{ Penicillium spp. } & \multicolumn{2}{|c|}{ Rhizopus spp. } \\
\hline & $\begin{array}{c}\text { Growth } \\
(\mathrm{mm})\end{array}$ & $\begin{array}{c}\text { Inhibitio } \\
\mathrm{n} \quad(\%)\end{array}$ & $\begin{array}{l}\text { Growth } \\
(\mathrm{mm})\end{array}$ & $\begin{array}{l}\text { Inhibition } \\
(\%)\end{array}$ & $\begin{array}{c}\text { Growth } \\
(\mathrm{mm})\end{array}$ & $\begin{array}{l}\text { Inhibition } \\
(\%)\end{array}$ & $\begin{array}{l}\text { Growth } \\
(\mathrm{mm})\end{array}$ & $\begin{array}{c}\text { Inhibition } \\
(\%)\end{array}$ & $\begin{array}{l}\text { Growth } \\
(\mathrm{mm})\end{array}$ & $\begin{array}{c}\text { Inhibition } \\
(\%)\end{array}$ \\
\hline $\begin{array}{c}\text { Carbendazim } \\
(0.2 \%)\end{array}$ & 00.00 & 100 & 00.00 & 100 & 00.00 & 100 & 00.00 & 100 & 33.00 & 23.43 \\
\hline Carboxin $(0.2 \%)$ & 00.00 & 100 & 00.00 & 100 & 00.00 & 100 & 00.00 & 100 & 24.86 & 42.34 \\
\hline Mancozeb $(0.2 \%)$ & 00.00 & 100 & 09.86 & 74.52 & 08.73 & 77.49 & 09.60 & 75.60 & 29.76 & 30.98 \\
\hline $\begin{array}{c}\text { Carbendazim }(0.1 \%) \\
+ \text { Carboxin }(0.1 \%)\end{array}$ & 00.00 & 100 & 00.00 & 100 & 00.00 & 100 & 00.00 & 100 & 00.00 & 100 \\
\hline Neem extracts $(5 \%)$ & 33.16 & 23.28 & 21.96 & 43.97 & 9.86 & 74.56 & 19.17 & 48.41 & 33.06 & 23.33 \\
\hline Control & 43.23 & - & 39.20 & - & 38.80 & - & 37.16 & - & 43.13 & - \\
\hline C.D at $5 \%$ & \multicolumn{2}{|c|}{0.46} & \multicolumn{2}{|c|}{0.72} & \multicolumn{2}{|c|}{0.55} & \multicolumn{2}{|c|}{0.86} & \multicolumn{2}{|c|}{0.92} \\
\hline S.E.(m) \pm & \multicolumn{2}{|c|}{0.14} & \multicolumn{2}{|c|}{0.23} & \multicolumn{2}{|c|}{0.17} & \multicolumn{2}{|c|}{0.27} & \multicolumn{2}{|c|}{0.29} \\
\hline
\end{tabular}


Fig.1 Evaluation of fungicide and bio-pesticide against major seed-borne pathogens

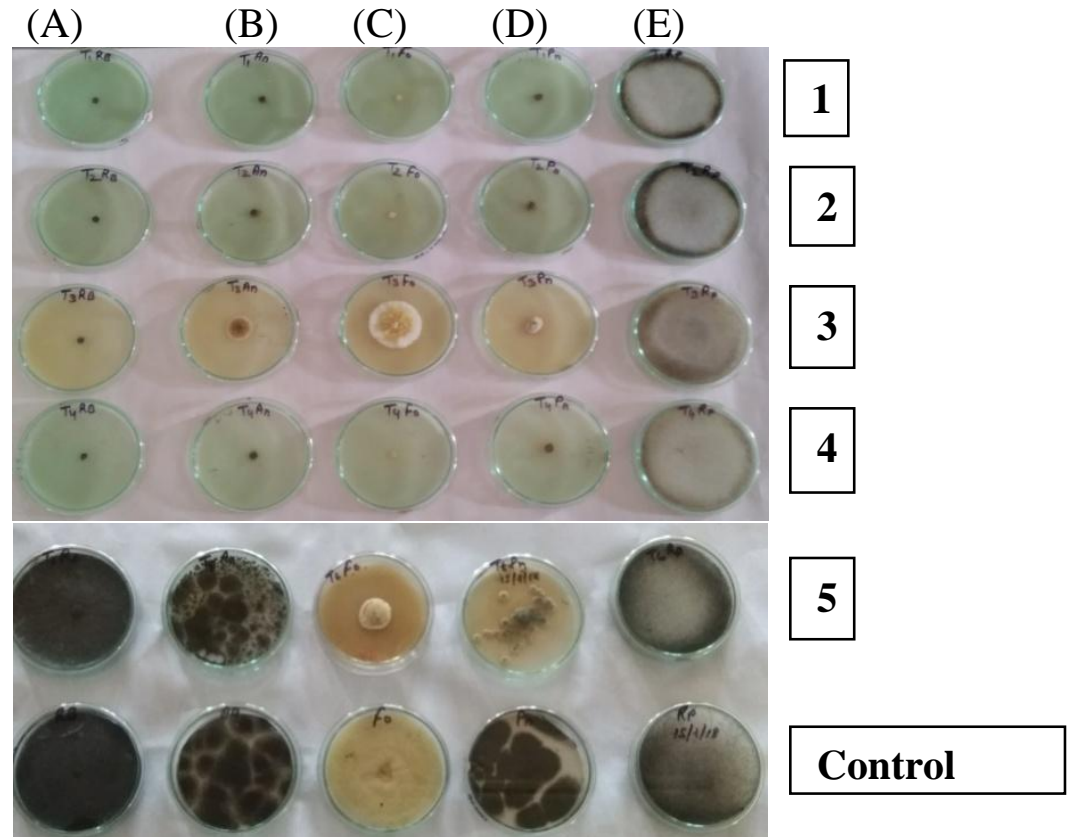

(A) R. bataticola, (B)A. niger, (C) F.oxysporium, (D) Penicillium spp. and (E) Rhizopus spp and 1. Carbendazim (0.2\%), 2. Carboxin (0.2\%), 3. Mancozeb $(0.2 \%)$, 4. Carbendazim $(0.1 \%)+$ (B) Carboxin $(0.1 \%)$ and 5 . Neem extract (5\%)

Chart.1 Percent inhibition of seed-borne pathogens of chickpea over control by Poisoned Food technique

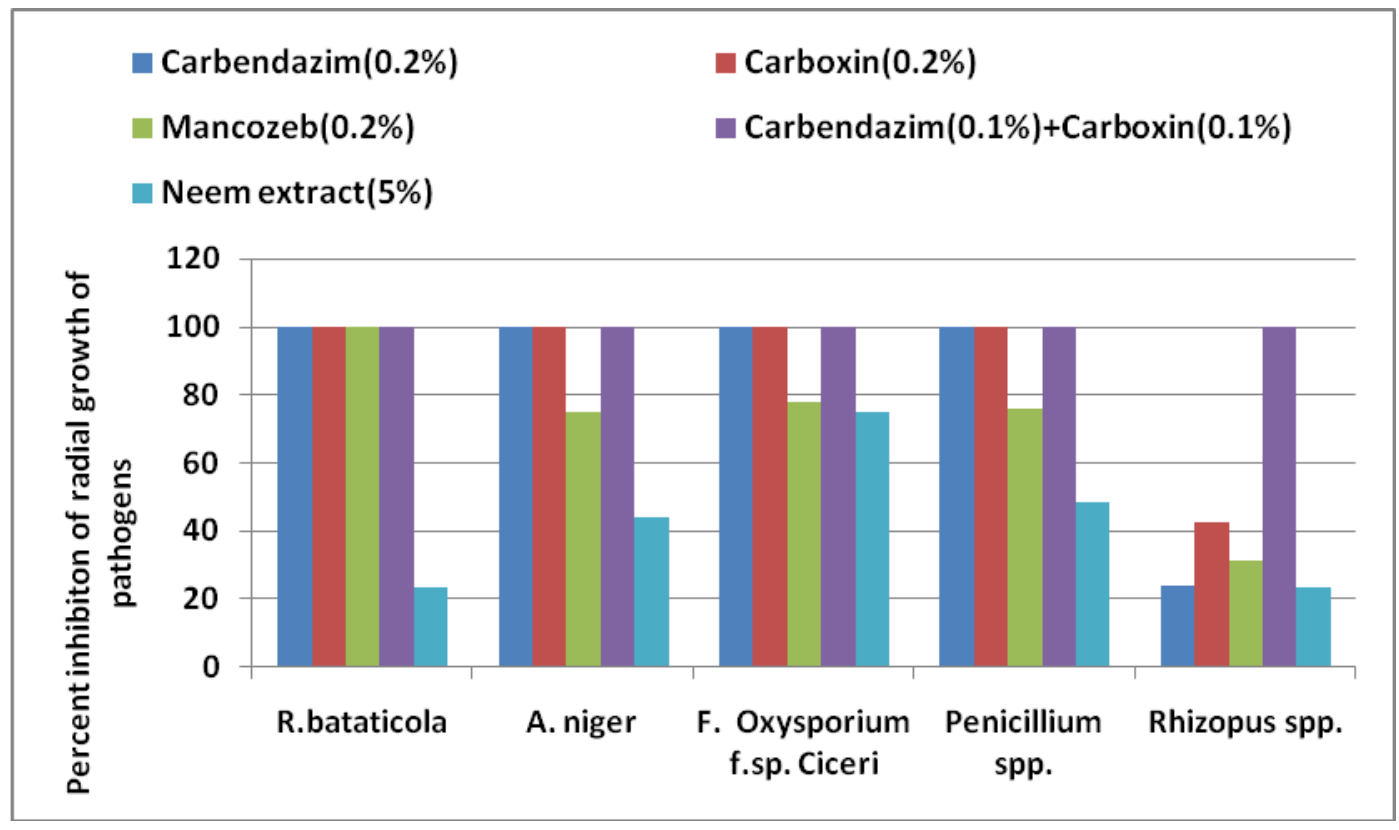


The seed-borne pathogens Rhizopus spp. was effectively completely (100\%) inhibited by the Carbendazim $(0.1 \%)+$ Carboxin $(0.1 \%)$ followed by Carboxin (42.34\%), Mancozeb $(30.98 \%)$, Carbendazim $(23.49 \%)$ and the lowest inhibition of the pathogens radial growth was showed by the Neem extract $(23.43 \%)$. These results are also reported by the previous workers. ${ }^{10,11 \& 12}$

\section{Acknowledgement}

The authors are grateful to College of Agriculture, Tikamgarh, JNKVV, Jabalpur M.P. for providing amenities during entire course of work.

\section{References}

Anonymous.2016. Annual progress report 2016: Indian Institute of Pulse Research Kanpur.

Anonymous, 2017a. Annual Progress Report 2017: Indian Institute of Pulse Research Kanpur.

Anonymous, 2017b. Advanced Estimated report of Directorate of Economics \& Statistics, Department of Agriculture and Corporation, Ministry of Agriculture and Corporation 03 :(142).

Van Emden, H.F, Ball, S.L. and Rao, M.R. 1988. Pest diseases and weed problems in pea, lentil and faba bean and chickpea. In summer field R.J. (ed.), World crops: cool season food legumes. Dordrecht: Kluwer, 519-534.

Nene, Y.L, Sheila, V.K. and Sharma, S.B. 1996. A World list of chickpea and pigeonpea pathogens. ICRISAT, 5th edition. 1-27.

Jalali, B.L. and Chand, H. 1992. Chickpea wilt. In: Plant Disease of International Importance (Singh, U.S., Mukhopadhyay, A.N., Kumar, J., and Chaube, H.S., ed.) Vol. I. Prentice Hall, Englewood Cliffs, N. J. USA, 429-444.

Dhingra, O.D. and Sinclair, J.B. 1993. Basic plant pathology methods.CBS Publishers and Distributors, New Delhi, 355.

Schmitz H. 1930. A suggested body metric method for food preservation industries and engineering chem. Analyst Ed 3:361-365.

Vincent JH. 1947. Distortion of Fungal Hyphae in the Presence of Certain Inhibitors. Nature, 15: 850.

Soma, D, Sapna, S. and Ashok, A. 2008. Efficiency of Fungicide on mycilial growth and enzyme production on Rhizoctonia solani and Fusarium oxysporium. Ann. Pl. Prot. Sc., 16(1):135-138.

Vinit K. S, Prem N, Biswas, S. K and Gajendra, P. S. 2010. Efficiency of fungicide for management of wilt disease of lentil caused by Fusarium oxysporum f.sp. lentis. Annl. Pl. Prot. Sci., 18(2):411-414.

Somu, R.,Thammaiah, N., Swamy, G.S.K, Kulkarni, M.S and Devappa, V. (2014). In vitro evaluation of fungicides against Fusarium oxysporum f. sp. cubense. Internat. J. Plant Protec., 7(1): 221-224.

\section{How to cite this article:}

Vandana Chadar, Shraddha Karcho, Mahesh B. Ghuge and Bhanwar, R.R. 2019. Evaluation of Fungicides and Botanicals against Major Seed- Borne Pathogen of Chickpea Seed Isolated from Tikamgarh District of Madhya Pradesh. Int.J.Curr.Microbiol.App.Sci. 8(12): 722-727. doi: https://doi.org/10.20546/ijcmas.2019.812.095 